DOI: 10.20472/IAC.2018.040.022

\author{
SUNEE HAEMAPRASITH \\ Faculty of Education, Srinakharinwirot University, , Thailand
}

\title{
EFFECTS OF PRODUCT-BASED LEARNING ON LEARNING ABILITIES AND SATISFACATION OF UNDERGRADUATE STUDENT TEACHERS
}

\begin{abstract}
:
The purposes of this study were to study learning abilities and satisfaction towards product-based learning of the undergraduate student teachers. The samples were 55 undergraduate student teachers who studied in the 3rd year in education program and registered in ED331 Methodologies for Creating Integrated Learning and ED332 Local Curriculum courses in the first semester of academic year 2018. The instruments were the lesson plans, the rubric criteria forms of students' abilities in doing products or projects and teamwork skills, an academic achievement test and a learning satisfaction questionnaire. The results were as follows:
\end{abstract}

प1. The scores on teamwork skills, and products or projects of the undergraduate student teachers who were taught through the product-based learning were higher than the criterion and the academic achievement was higher than the criterion.

प2. The mean score of the satisfaction towards product-based learning of the undergraduate student teachers was at the high level both overall and knowledge and benefit aspects at the .01 level of statistical significance.

प3. The undergraduate student teachers had positively comments towards product-based learning such as deep understanding both theory and real practice about teaching strategies, various activities design, writing lesson plans, reflection and new idea/experience exchange.

\section{Keywords:}

Product-based learning, Teamwork skills, Academic achievement, Product or Project

JEL Classification: 123 